\title{
OBSERVATIONS ON RAT EGGS TRANSPLANTED TO THE MOUSE UTERUS
}

\author{
D. M. POTTS, ${ }^{*}$ I. B. WILSON ANd M. S. R. SMITH \\ Department of Anatomy, University of Cambridge, Department of Zoology, \\ University College of North Wales, Bangor, Caernarvonshire, and Department of Zoology, \\ University of Southampton
}

(Received 5th fune 1969)

\begin{abstract}
Summary. The ultrastructure of rat blastocysts $(114 \mathrm{hr}$ p.c.) transferred to the uterus of pseudopregnant mice $(80 \mathrm{hr}$ p.c.) was observed 24 to $36 \mathrm{hr}$ after transfer. The morphology of the blastocyst and of the uterine epithelium was apparently normal for the species and time of pregnancy, but the plasma membranes of the trophoblast and uterine epithelium failed to establish the intimate contact which is characteristic of the later stages of normal implantation.
\end{abstract}

\section{INTRODUCTION}

Experimental inter-specific transfer of eggs has been attempted between goats and sheep (Warwick \& Berry, 1949; Lopyrin, Loginova \& Karpor, 1951), between rats and mice (Tarkowski, 1962) and between rats, mice, guinea-pigs and rabbits in various combinations (Briones \& Beatty, 1954). A variety of host environments appear to be tolerated by the pre-implantation blastocyst, as shown by the example of sheep eggs continuing normal development after a period of 'culture' in the rabbit uterus (Averill, Adams \& Rowson, 1955). When experimental transplantation of the blastocyst is performed, development will continue in a variety of ectopic sites in host males as well as females (Kirby, 1962). However, in the case of inter-specific transfers to the uterus, development does not proceed beyond the attachment phase of implantation (Tarkowski, 1962). This paper is concerned with the ultrastructure of rat eggs transferred to the mouse uterus.

The ultrastructure of normal implantation in the mouse has been studied by Potts (1966a, 1968), Potts \& Wilson (1967) and Reinius (1967) and in the rat by Mayer, Nilsson \& Reinius (1967) and Enders \& Schlafke (1967).

\section{MATERIALS AND METHODS}

Blastocysts were collected from rats at approximately $114 \mathrm{hr}$ post coitum (p.c.) and transferred to pseudopregnant female mice at approximately $80 \mathrm{hr}$ p.c. A total of sixty-two rat eggs were transferred to twelve mice. The mice were killed 24 to $36 \mathrm{hr}$ after transfer, fixed in cold buffered gluteraldehyde, post-osmicated

* Present address: International Planned Parenthood Federation, 18-20 Lower Regent Street, London, S.W.1. 
and then sectioned for the electron microscope by the double sectioning technique developed by Potts (1966b). Only six of the blastocysts were studied in detail, since most of the sixty-two were not recovered.

\section{OBSERVATIONS}

Following transfer to the mouse uterus, the zona pellucida disintegrated around the rat blastocysts, which grew to about $100 \mu$ at maximum diameter and lay loosely in contact with the antimesometrial epithelium. No evidence of hatching or of any alteration in the timing of the loss of the zona pellucida was found in the small series studied. The trophoblast consisted of a shell of cells united by tight junctions; the total thickness of the cells surrounding the nucleus was 3 to $5 \mu$ but elsewhere the thickness was greatly attenuated and might be reduced to $0 \cdot 1 \mu$. There were blunt projections on the outer surface of the trophoblast and longer, more villous-like projections on the surface facing the blastocoele cavity. Caveolae were found on the outer surface. The endoplasmic reticulum was sparse, having numerous free ribosomes.

The inner-cell-mass cells were ovoid, 8 to $10 \mu$ at maximum diameter and separated by an irregular extra-cellular space. The inner cell mass was usually orientated towards the mesometrial side of the uterus, but this relationship was not constant. There was variation in cytoplasmic and nuclear staining of the blastocyst cells; both the trophoblast and inner-cell-mass cells also contained complex dense inclusions sometimes attaining $5 \mu$ in diameter. Morphological evidence has been found for cellular degeneration and cell fragments were sometimes found in the blastocoele cavity (Pl. 1, Fig. 1).

The mouse uterine epithelial cells were 10 to $15 \mu$ deep and 8 to $10 \mu$ broad. They had an irregular surface with bulbous processes up to $1 \mu$ long (Pl. 1, Fig. 1). They were united laterally by tight junctions and rested on a welldefined basement membrane. They were rich in mitochondria and lipid droplets were distributed throughout the cytoplasm both above and below the nucleus.

The blastocyst and the uterine epithelium were often closely related for part of their circumferences. Usually a gap of 2 to $3 \mu$ intervened but sometimes this was reduced to $0.5 \mu$ or less, and occasionally the blastocyst and surface of the uterine epithelium were in contact. Also, in most cases, irregular fragmented membranes were found between the blastocyst and uterine epithelium (Pl. 1, Fig. 1). Various degrees of apposition were found in different specimens; in one, the surface of the uterine epithelial cells most closely related to the blastocyst was flattened and there was some thickening of the underlying basement

EXPLANATION OF PLATE 1

All sections double stained with lead citrate and uranyl acetate. t-trophoblast; e-uterine epithelium.

Fig. 1. Transverse section of rat blastocyst in mouse uterus $24 \mathrm{hr}$ after transfer. $\times 8700$.

Fig. 2. Close association of trophoblast and uterine epithelium. A cytoplasmic process (arrow) from an epithelial cell is partially encircled by trophoblast cytoplasm. $\times 21,000$. Fig. 3. Normal implantation in the rat in which the blastocyst is of the same maturity as that illustrated in Fig. $2 . \times 21,000$. 
PLATE 1
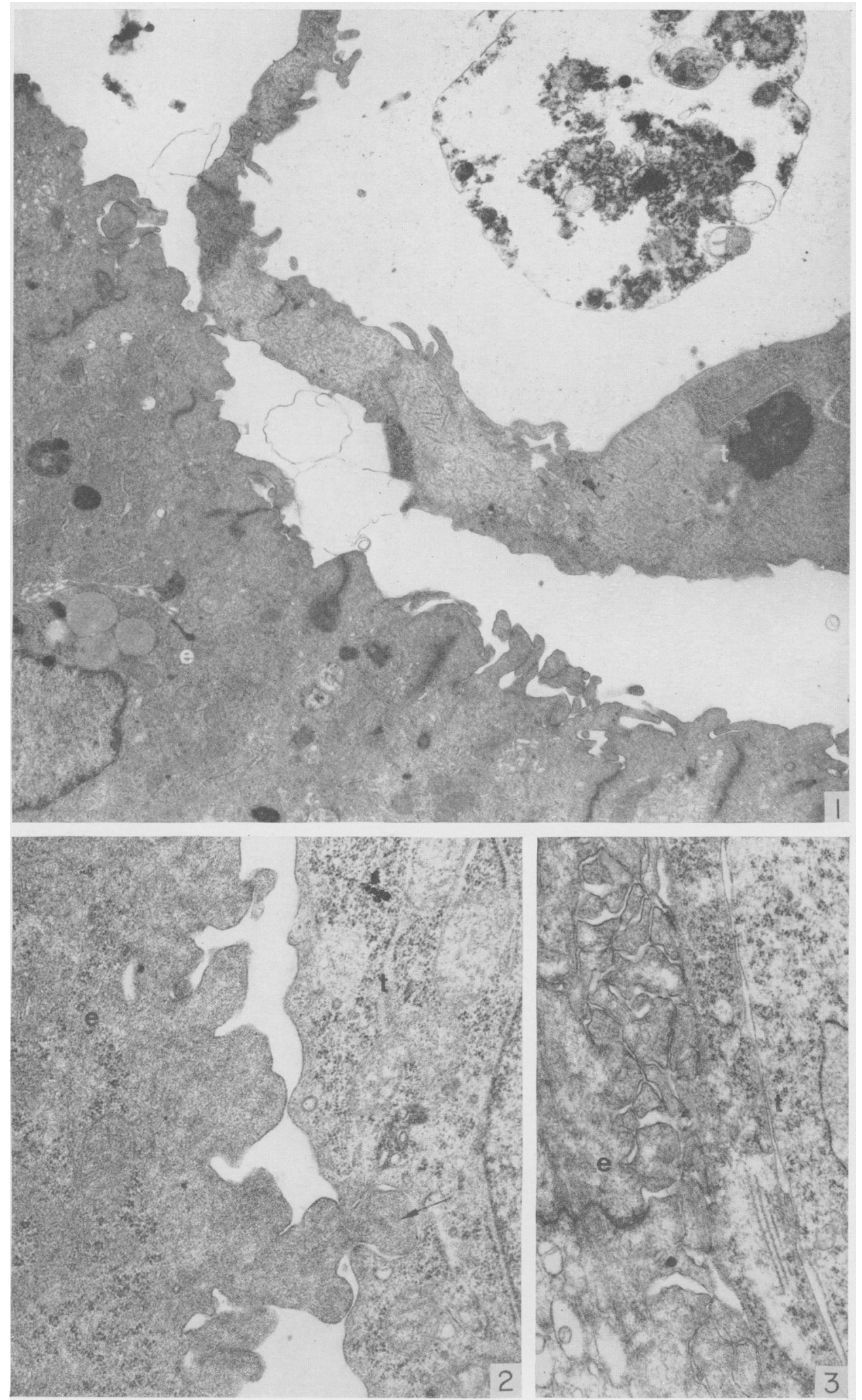
membrane. In another specimen, the trophoblast and epithelial cells were related at three or four sites at the abembryonic pole of the blastocyst ( $\mathrm{Pl}$. 1, Fig. 2). At these sites, bulbous processes reaching approximately $1 \mu$ above the surface of the epithelial cells were partially engulfed by trophoblast cells. There was no specialization of either blastocyst or uterine epithelial plasma membranes in this region. Localized changes in the sub-epithelial tissues, extending for approximately $100 \mu$ could be recognized in the vicinity of a blastocyst; the stromal cells were enlarged and the extra-cellular space was reduced.

\section{DISGUSSION}

The ultrastructure of the uterine epithelium appears to be similar in a number of rodents, and there are broad similarities between all mammals that have been studied (Nilsson, 1962; Potts, 1969).

In rats and mice under normal circumstances, the luminal surface of the uterine epithelium undergoes a similar series of morphological changes at the time of implantation. The regular villous border of the epithelial cells at the beginning of the attachment phase becomes transformed into irregular cytoplasmic projections. Subsequently, the plasma membranes of trophoblast and epithelium come to lie nearly parallel and in very close apposition. Attachment usually occurs at about $100 \mathrm{hr}$ p.c. in the mouse and about $120 \mathrm{hr}$ p.c. in the rat. The full evolution of cellular relationships from pre-attachment to full adherence takes less than 1 day and leads on to the loss of the uterine epithelial cells. During delayed implantation, epithelial microvilli persist as a prominent feature and their loss appears to be associated with the onset of a physiologically defined period of uterine receptivity (Potts \& Psychoyos, 1967).

When developing in the mouse uterus, the rat blastocyst has apparently normal morphology, though there may be a slight increase in embryonic cell death. The host uterine tissues appear normal also. Degenerating cells are always found at this stage of pregnancy and it is not possible to draw quantitative conclusions from the small series available. Partial flattening of the epithelial plasma membrane, characteristic of the adherent stage of normal implantation (Pl. 1, Fig. 3), has occurred in some of the specimens described here, but the maternal (mouse) and embryonic cells (rat) have not come into close apposition. The apparent engulfing of epithelial protoplasmic protrusions by the trophoblast has not been described for normal implantation (Pl. 1, Fig. 2).

Tarkowski (1962) has described how the rat blastocyst in the mouse uterus evoked a normal decidual reaction and became enclosed in a uterine crypt, though none survived beyond $170 \mathrm{hr}$ p.c. It appeared in most cases that the breakdown of the uterine epithelium was not complete enough to allow the rat blastocyst to make proper contact with the host mucosa.

Our present observations indicate that incompatibility between the foreign blastocyst and the host uterus may become manifest at the ultrastructural level at the first attempt to establish the cellular contacts necessary for implantation. The failure of the rat and mouse plasma membranes to come into the close apposition typical of this stage of normal implantation, may simply reflect species differences in the composition of the cell surfaces, precluding establish- 
ment of the normal train of events which might lead to successful implantation and survival.

\section{ACKNOWLEDGMENTS}

This research was partly supported by a grant from the Medical Research Council (D.M.P.) and a Wellcome Trust Fellowship (M.S.R.S.). We are grateful to Mrs S. Barton for her assistance at all stages of the work.

\section{REFERENCES}

Averill, R. L. W., Adams, C. E. \& Rowson, L. E. A. (1955) Transfer of mammalian ova between species. Nature, Lond. 176, 167.

Briones, H. \& Beatry, R. A. (1954) Inter-specific transfers of rodent eggs. F. exp. Zool. 125, 99.

ENDERS, A. C. \& Schlapke, S. (1967) A morphological analysis of the early implantation stages in the rat. Am. J. Anat. 120, 185.

KIRBY, D. R. S. (1962) Reciprocal transplantation of blastocysts between rats and mice. Nature, Lond. $194,785$.

Lopyrin, A. I., Loginova, N. V. \& Karpor, P. L. (1951) The effect of changed conditions during embryogenesis on growth and development in lambs. Sov. Zootekh. 6, 83.

Mayer, G., Nilsson, O. \& Reinius, S. (1967) Gell membrane changes of uterine epithelium and trophoblast during blastocyst attachment in rat. Z. Anat. EntwGesch. 126, 43.

NiLsson, O. (1962) Correlation of structure to function of the luminal surface in the uterine epithelium of mouse and man. Z. Zellforsch. mikrosk. Anat. 56, 803.

Potrs, D. M. (1968) The ultrastructure of implantation in the mouse. F. Anat. 103, 77.

Poтrs, D. M. (1969) The ultrastructure of egg implantation. In: Advances in Reproductive Physiology, Vol. 4, p. 241. Ed. Anne McLaren. Logos Press, London.

Potтs, D. M. \& Psychoyos, A. (1967) Evolution de l'ultrastructure des relations ovoendométriales sous l'influence de l'oestrogène, chez la ratte en retard expérimental de nidation.C.r. hebd. Séanc. Acad. Sci., Paris, 264, 370.

PotTs, D. M. \& Wrison, I. B. (1967) The preimplantation conceptus of the mouse at 90 hours postcoitum. 7. Anat. 102, 1.

Potrs, M. (1966a) The attachment phase of ovoimplantation. Am. F. Obstet. Gynec. 96, 1122.

PotTs, M. (1966b) A method for locating specific histological features for electron microscopy. $f l R$. microsc. Soc. 85, 97.

Reinius, S. (1967) Ultrastructure of blastocyst attachment in the mouse. Z. Zellforsch. mikrosk. Anat. 77, 257.

TARKowski, A. K. (1962) Inter-specific transfers of eggs between rat and mouse. F. Embryol. exp. Morph. 10, 476.

WARWICK, B. L. \& BERRY, R. O. (1949) Inter-generic and intra-specific embryo transfers in sheep and goats. F. Hered. 40, 297. 